\title{
Obesity and chronic obstructive pulmonary disease: Is fatter really better?
}

\author{
Roxana G Galesanu MD MSc${ }^{1}$, Sarah Bernard MSc ${ }^{1}$, Karine Marquis PhD ${ }^{1}$, Yves Lacasse MD MSc ${ }^{1}$, \\ Paul Poirier MD PhD ${ }^{1}$, Jean Bourbeau MD MSc${ }^{2}$, François Maltais MD ${ }^{1}$
}

RG Galesanu, S Bernard, K Marquis, et al. Obesity and chronic obstructive pulmonary disease: Is fatter really better? Can Respir J 2014;21(5):297-301.

BACKGROUND: Overweight/obesity is associated with longer survival in chronically ill patients, a phenomenon referred to as the 'obesity paradox'. OBJECTIVE: To investigate whether the obesity paradox in patients with chronic obstructive pulmonary disease (COPD) is due to fat accumulation or confounding factors.

METHODS: A total of 190 patients with stable COPD who underwent a mean ( \pm SD) follow-up period of $72 \pm 34$ months were enrolled. Anthropometry, pulmonary function tests, midthigh muscle cross-sectional area obtained using computed tomography $\left(\mathrm{MTCS}_{\mathrm{CT}}\right)$, arterial blood gas and exercise testing data were measured at baseline. Patients were categorized into two subgroups according to body mass index (BMI) $<25 \mathrm{~kg} / \mathrm{m}^{2}$ or $\geq 25 \mathrm{~kg} / \mathrm{m}^{2}$ (normal and overweight/obese, respectively).

RESULTS: Seventy-two patients (38\%) died during the follow-up period. Survival tended to be better in the overweight/obese patients but this difference did not reach statistical significance. Overweight/obese patients had better lung function and a larger MTCSA $\mathrm{CT}_{\mathrm{CT}}$ than those with normal BMI $(\mathrm{P}<0.001)$. Overweight/obese patients also had a significantly higher peak work rate than patients with normal $\mathrm{BMI}(\mathrm{P}<0.001) . \mathrm{PaO}_{2}$ and $\mathrm{PaCO}_{2}$ were not significantly different in the two groups. When adjusted for $\mathrm{PaCO}_{2}$, peak work rate and MTCSA survival in overweight/obese patients disappeared. In fact, when these variables were considered in the survival analysis, patients with lower BMI tended to have better survival.

CONCLUSION: These results suggest that important confounders, such as hypercapnia, exercise capacity and muscle mass, should be considered when interpreting the association between increased BMI and survival in patients with COPD.

Key Words: COPD; Muscle; Obesity; Survival

\section{L'obésité et la maladie pulmonaire obstructive chronique : est-il vraiment préférable d'être plus gras?}

HISTORIQUE : L'embonpoint et l'obésité s'associent à une survie plus longue chez les patients atteints d'une maladie chronique. Ce phénomène s'appelle « le paradoxe de l'obésité ».

OBJECTIF : Chez les patients atteints de maladie pulmonaire obstructive chronique (MPOC), examiner si le paradoxe de l'obésité est causé par l'accumulation de graisse ou par des facteurs confusionnels.

MÉTHODOLOGIE : Au total, 190 patients ayant une MPOC stable, suivis pendant une période moyenne ( \pm ÉT) de $72 \pm 34$ mois, ont participé à l'étude. En début d'étude, les chercheurs ont mesuré les données tirées des facteurs anthropométriques, des épreuves de fonction pulmonaire, de la surface musculaire transversale à mi-cuisse par tomodensitométrie $\left(\mathrm{SMTM}_{\mathrm{TD}}\right)$, des gaz artériels et des épreuves à l'effort. Les patients ont été classés en deux sousgroupes d'après leur indice de masse corporelle (IMC) inférieur à $25 \mathrm{~kg} / \mathrm{m}^{2}$ ou d'au moins $25 \mathrm{~kg} / \mathrm{m}^{2}$ (normal et embonpoint ou obésité, respectivement).

RÉSULTATS : Soixante-douze patients (38\%) sont décédés pendant la période de suivi. La survie avait tendance à être plus longue chez les patients obèses ou faisant de l'embonpoint, mais cette différence n'était pas statistiquement significative. Les patients obèses ou qui faisaient de l'embonpoint avaient une meilleure fonction pulmonaire est une SMTM $\mathrm{TD}_{\mathrm{D}}$ plus large que ceux ayant un IMC normal $(\mathrm{P}<0,001)$. Ils avaient également un taux d'effort de pointe plus élevé que les patients ayant un IMC normal $(\mathrm{P}<0,001)$. La $\mathrm{PaO}_{2}$ et la $\mathrm{PaCO}_{2}$ ne présentaient pas de différence significative entre les deux groupes. Après avoir été rajustée pour tenir compte de la $\mathrm{PaCO}_{2}$, du taux d'effort de pointe et de la SMTM $\mathrm{TD}_{\mathrm{TD}}$, la tendance à une meilleure survie chez les patients obèses ou faisant de l'embonpoint disparaissait. En fait, lorsque ces variables étaient prises en compte dans l'analyse de survie, les patients dont l'IMC était plus faible avaient tendance à présenter une meilleure survie.

CONCLUSION : Selon ces résultats, il faut tenir compte d'importantes variables confusionnelles, telles que l'hypercapnie, la capacité à l'exercice et la masse musculaire, au moment d'interpréter l'association entre un IMC plus élevé et la survie chez les patients ayant une MPOC.
Chronic obstructive pulmonary disease (COPD) is a global health epidemic. COPD is expected to become the third-leading cause of death and the fifth cause of chronic disability worldwide by 2020 (1). Aside from progressive airflow limitation, lung hyperinflation and progressive shortness of breath, COPD also has significant systemic repercussions (1) including weight loss and skeletal muscle atrophy. These body composition abnormalities are associated with increased mortality, independent of lung function impairment (2-4).

The current global obesity epidemic is changing the nature of the nutritional abnormalities observed in patients with COPD. In fact, a larger proportion of patients with COPD exhibit overweight and obesity rather than normal or underweight (5-8). In the general population, obesity is associated with systemic hypertension, type 2 diabetes, cancer and cardiovascular diseases, which all contribute to reduced life expectancy $(9,10)$. However, in patients with chronic heart $(11,12)$ or kidney diseases (13), overweight and obesity are associated with prolonged survival, a phenomenon referred to as the 'obesity paradox' or 'reverse epidemiology' $(11,14)$. Across studies, this observation appears to be robust and is valid up to a body mass index (BMI) of $40 \mathrm{~kg} / \mathrm{m}^{2}$ (15). The obesity paradox may also apply to patients with COPD, as suggested by the inverse relationship between mortality and BMI, particularly in patients with severe disease (16-18).

Why would excess body weight protect against premature mortality in chronic diseases such as COPD? In a previous study, we reported that this epidemiological association could be explained by several confounding variables influencing the relationship between body weight and survival that are not typically taken into account in large epidemiological studies (5). For example, we $(5,6)$ and others (19) have reported that overweight or obese patients with COPD may receive medical attention earlier (ie, while having better preserved expiratory flows and less hyperinflation compared with their lean counterparts). In addition, obese patients with COPD not only have more adipose tissue, they also have more muscle, which may offer a survival advantage (2-5). Finally, peak oxygen consumption $\left(\mathrm{VO}_{2}\right)$, a parameter positively associated with longer survival in COPD (20), is higher in obese patients with COPD than in their normal-BMI

${ }^{1}$ Centre de recherche, Institut Universitaire de Cardiologie et de Pneumologie de Québec, Université Laval, Québec; ${ }^{2}$ Respiratory, Epidemiology and Clinical Research Unit, Montreal Chest Institute of the Royal Victoria Hospital, McGill University Health Centre, McGill University, Montreal, Quebec

Correspondence: Dr François Maltais, Institut Universitaire de Cardiologie et de Pneumologie de Québec, 2725 Chemin Ste-Foy, Québec, Québec G1V 4G5. Telephone 418-656-4747, fax 418-656-4762, e-mail francois.maltais@med.ulaval.ca 
counterparts (21). As such, increased adiposity may not account for better survival in patients with COPD and increased BMI.

The present study was undertaken to address the following questions: is overweight/obesity associated with better survival in COPD?; and are there important confounding factors that should be taken into account when evaluating the relationship between survival and BMI in this disease? We hypothesized that increased BMI would be associated with improved survival, an observation that can be largely explained by confounders, such as severity of lung impairment, muscle mass and exercise capacity, that are not typically considered in large epidemiological studies investigating the relationship between body weight and survival in COPD. To test these hypotheses, we took advantage of a longitudinal cohort of patients with COPD that was recruited between 1995 and 2005 in our institution. Part of the data pertaining to this cohort have been published in an investigation of the role of muscle wasting and survival in COPD (2). Since this first publication, the cohort has been expanded and the follow-up has been prolonged.

\section{METHODS}

\section{Patient population}

Patients with COPD were prospectively enrolled in a longitudinal cohort as they entered the rehabilitation program of the authors' institution between 1995 and 2005. The diagnosis of COPD was based on current or past smoking history, clinical assessment and pulmonary function tests showing not fully reversible airflow obstruction (postbronchodilator forced expiratory volume in $1 \mathrm{~s}\left[\mathrm{FEV}_{1}\right] /$ forced vital capacity $[\mathrm{FVC}]<0.7$ ). Patients with asthma, a primary diagnosis of cardiac failure, dementia or unstable psychological conditions were excluded. The research protocol was approved by the Ethics Committee of the Institut Universitaire de cardiologie et de pneumologie de Québec and all patients gave informed consent to participate in the study.

The 190 enrolled patients were categorized into two subgroups based on BMI $<25 \mathrm{~kg} / \mathrm{m}^{2}$ (normal weight $[\mathrm{n}=91]$ ) or $\geq 25 \mathrm{~kg} / \mathrm{m}^{2}$ (overweight/obese [n=99]) according to the National Institutes of Health and WHO (22).

\section{Anthropometric measurements}

Body weight and height were measured in all patients, and BMI was calculated as weight $(\mathrm{kg})$ divided by height $(\mathrm{m})$ squared.

\section{Computed tomography of the thigh}

A computed tomography scan of the right thigh halfway between the pubic symphisis and the femoral condyles was performed using a fourth-generation Toshiba Scanner 9005 (Toshiba Inc, Japan) according to the protocol described by Bernard et al (23). For technical reasons, midthigh muscle cross-sectional area obtained using computed tomography $\left(\mathrm{MTCSA}_{\mathrm{CT}}\right.$ ) could not be obtained in three patients.

\section{Pulmonary function tests and arterial blood gases}

Standard spirometry was performed according to American Thoracic Society criteria (24). The parameters retained for statistical analysis were $\mathrm{FEV}_{1}, \mathrm{FVC}$ and the $\mathrm{FEV}_{1} / \mathrm{FVC}$ ratio. Equations used to predict normal values were those from Quanjer et al (25). Arterial blood was drawn from radial artery puncture while patients were breathing room air. Partial pressure of oxygen $\left(\mathrm{PaO}_{2}\right)$ and partial pressure of carbon dioxide $\left(\mathrm{PaCO}_{2}\right)$ were measured using a blood gas machine (AVL 995; AVL Scientific Corp, USA) in 175 patients.

\section{Exercise testing}

A symptom-limited incremental cycle exercise test was performed to determine peak exercise capacity. The exercise test was performed on room air, seated on an electrically braked ergocycle (Quinton Corival 400; A-H Robins, USA) and starting at a work rate of $10 \mathrm{~W}$. Each exercise step lasted $1 \mathrm{~min}$ and increments of $10 \mathrm{~W}$ were used until maximal exercise workload was reached. Peak work rate, defined as the highest exercise workload tolerated for at least $30 \mathrm{~s}$, was used as the marker of peak exercise capacity. For technical reasons, peak work rate data were available for 169 patients.

\section{Follow-up}

Patients were followed for all-cause mortality until February 28, 2007. The medical chart of each patient was reviewed to establish the cause of mortality. For patients deceased outside the authors' hospital, this information were obtained from Institut de la statistique du Québec, a governmental organization to which all deaths in Quebec are reported.

\section{Statistical analysis}

Descriptive statistics were used to characterize the study population at baseline. Continuous variables are expressed as mean \pm SD while discrete variables are shown as percentages. The level of statistical significance was set at $\mathrm{P}<0.05$. Between-group comparisons were made using the Student's $t$ test or Mann-Whitney rank sum test if the variables were not normally distributed as verified using the Shapiro-Wilk's statistic. Unadjusted survival curves according to the BMI subgroup were drawn from the Kaplan-Meier statistics. A univariate analysis based on the Cox proportional hazards model was conducted in which each of the potential predictors of mortality were entered as independent variables (age, sex, $\mathrm{FEV}_{1}, \mathrm{BMI}, \mathrm{MTCSA}_{\mathrm{CT}}$, peak work rate, $\mathrm{PaO}_{2}$ and $\mathrm{PaCO}_{2}$ ) and the survival status as the dependent variable. Stepwise regression and best subset models were used to proceed to multivariate analysis. Both methods highlighted $\mathrm{MTCSA}_{\mathrm{CT}}, \mathrm{PaCO}_{2}$ and peak work rate as important variables to predict mortality, and were entered into the final regression model from which the adjusted survival curves were constructed. Whether collinearity was present in the model was tested using the condition index, a condition number $>30$ reflecting significant collinearity (26). Data were analyzed using SAS version 9.1 (SAS Institute Inc, USA). The results of the regression analyses are listed in terms of estimated hazard ratios (HR) with corresponding $95 \%$ CIs.

\section{Patient characteristics}

\section{RESULTS}

The characteristics of the study population are presented in Table 1. On average, patients had moderate to severe airflow obstruction with a mean ( \pm SD) BMI of $26 \pm 5 \mathrm{~kg} / \mathrm{m}^{2}$, ranging from $14.8 \mathrm{~kg} / \mathrm{m}^{2}$ to $48.1 \mathrm{~kg} / \mathrm{m}^{2}$. The mean MTCSA $\mathrm{CT}_{\text {was }} 74.0 \pm 17.5 \mathrm{~cm}^{2}$ which is reduced compared with a MTCSA CT $_{\text {of }} 109.6 \pm 15.6 \mathrm{~cm}^{2}$ obtained in healthy or individuals with similar age previously studied by the authors' group (23). $\mathrm{PaO}_{2}$ and $\mathrm{PaCO}_{2}$ were within normal limits and peak work capacity was reduced to an average of $65 \pm 33 \mathrm{~W}$.

Differences between normal weight and overweight/obese: Subjects in both BMI groups had similar age and height, and the women to men ratio was not significantly different. Patients in the overweight/obese group had significantly better lung function as indicated by a higher $\mathrm{FEV}_{1}(\mathrm{P}<0.001)$, a larger MTCSA $\mathrm{CT}(\mathrm{P}<0.001)$ and higher peak work rate $(\mathrm{P}<0.001)$ than those in the normal weight group. $\mathrm{PaO}_{2}$ and $\mathrm{PaCO}_{2}$ were not statistically different between the two groups.

BMI and survival: The mean follow-up period was $72 \pm 34$ months (range five to 139 months). During this period, 72 patients died (11 women and 61 men), corresponding to a mortality rate of $38 \%$. The cause of death could be determined in 64 of the 72 deceased patients (Figure 1). The most common causes of death was COPD or COPD-related complications $(n=37)$, acute myocardial infarction or cardiovascular diseases such as atherosclerosis or valvular disease $(n=6)$, lung cancer $(n=4)$ and other malignant tumours $(n=10)$.

As reported in Table 2, patients who survived had a significantly larger MTCSA $_{C T}(P=0.008)$ and a higher peak work rate capacity $(\mathrm{P}<0.001)$ than those who died. Also, survivors had significantly greater $\mathrm{PaO}_{2}$ than those who died $(\mathrm{P}=0.013)$. Deceased patients tended to have a lower BMI compared with survivors; however, the difference did not reach statistical significance $(\mathrm{P}=0.058)$.

\section{Predictors of survival}

The unadjusted survival curves for the two BMI subgroups are shown in Figure 2A. There was a tendency of patients with BMI $\geq 25 \mathrm{~kg} / \mathrm{m}^{2}$ to have a better survival compared with patients with a BMI $<25 \mathrm{~kg} / \mathrm{m}^{2}$ 
TABLE 1

Subject characteristics according to body mass index (BMI)

\begin{tabular}{|c|c|c|c|}
\hline \multirow[b]{2}{*}{ Variable } & \multicolumn{3}{|c|}{ Subjects } \\
\hline & $\begin{array}{c}\text { All } \\
(n=190)\end{array}$ & $\begin{array}{c}\mathrm{BMI}<25 \mathrm{~kg} / \mathrm{m}^{2} \\
(\mathrm{n}=91)\end{array}$ & $\begin{array}{c}\text { BMI } \geq 25 \mathrm{~kg} / \mathrm{m}^{2} \\
(\mathrm{n}=99)\end{array}$ \\
\hline Age, years & $65 \pm 8$ & $65 \pm 9$ & $65.21 \pm 7$ \\
\hline Sex, female/male $(\% / \%)$ & $26 / 164(14 / 86)$ & $15 / 76(16 / 84)$ & $11 / 88(11 / 89)$ \\
\hline Height, m & $1.67 \pm 0.08$ & $1.66 \pm 0.08$ & $1.67 \pm 0.08$ \\
\hline Weight, kg & $72 \pm 16$ & $59 \pm 9$ & $83 \pm 12$ \\
\hline BMI, $\mathrm{kg} / \mathrm{m}^{2}$ & $26 \pm 5$ & $22 \pm 3$ & $30 \pm 4$ \\
\hline $\mathrm{FEV}_{1}, \mathrm{~L}$ & $1.10 \pm 0.46$ & $0.93 \pm 0.40$ & $1.26 \pm 0.45$ \\
\hline $\mathrm{FEV}_{1}, \%$ predicted & $41 \pm 15$ & $35 \pm 12$ & $46 \pm 15^{*}$ \\
\hline FVC, L & $2.50 \pm 0.76$ & $2.35 \pm 0.72$ & $2.62 \pm 0.78$ \\
\hline FVC, \% predicted & $72 \pm 18$ & $70 \pm 17$ & $74 \pm 19$ \\
\hline $\mathrm{FEV}_{1} / \mathrm{FVC}, \%$ & $44 \pm 12$ & $40 \pm 9$ & $49 \pm 12$ \\
\hline Peak work rate, W & $65 \pm 33$ & $54 \pm 32$ & $74 \pm 31^{*}$ \\
\hline $\mathrm{PaO}_{2}, \mathrm{mmHg}$ & $81 \pm 12$ & $81 \pm 14$ & $81 \pm 11$ \\
\hline $\mathrm{PaCO}_{2}, \mathrm{mmHg}$ & $41 \pm 5$ & $42 \pm 5$ & $41 \pm 5$ \\
\hline MTCSA $_{\mathrm{CT}}, \mathrm{cm}^{2}$ & $74 \pm 18$ & $66 \pm 16$ & $81 \pm 15^{*}$ \\
\hline
\end{tabular}

Data presented as mean $\pm S D$ unless otherwise indicated. ${ }^{*} P<0.001$ versus patients with $B M I<25 \mathrm{~kg} / \mathrm{m}^{2}$. FEV 1 Forced expiratory volume in $1 \mathrm{~s}$; FVC Forced vital capacity; MTCSA $C T$ Midthigh muscle cross-sectional area obtained using computed tomography scan; $\mathrm{PaCO}_{2}$ Partial pressure of carbon dioxide; $\mathrm{PaO}_{2}$ Partial pressure of oxygen

$(\mathrm{P}=0.13)$. Age, $\mathrm{BMI}, \mathrm{FEV}_{1}, \mathrm{MTCSA}_{\mathrm{CT}}$, peak work rate and $\mathrm{PaCO}_{2}$ significantly correlated with mortality (Table 3 ). Multiple regression analysis revealed that MTCSA $_{C T}$ and peak work rate were independent predictors of survival (Table 4). $\mathrm{PaCO}_{2}$ was kept in the final model because its association with survival barely missed statistical significance $(\mathrm{P}=0.073)$. In this model, age and $\mathrm{FEV}_{1}$, which were significantly associated with mortality in the univariate analysis, did not emerge as significant mortality predictors. According to the model, for every unit increment in peak work rate and MTCSA $_{\mathrm{CT}}$, mortality decreased by $1.4 \%$ and $2 \%$, respectively. Each unit increment in $\mathrm{PaCO}_{2}$ increased mortality by $4.3 \%$ (Table 4 ). The tendency for a survival advantage of patients with a $\mathrm{BMI} \geq 25 \mathrm{~kg} / \mathrm{m}^{2}$ vanished when the survival curves were adjusted for MTCSA $\mathrm{CT}_{2}, \mathrm{PaCO}_{2}$ and peak work rate (Figure $2 \mathrm{~B}$ ). In the model, the maximal value of the condition number was 2.05 , indicating that collinearity was not an issue. Moreover, fitting a new model without adjusting for MTCSA $\mathrm{CT}_{\mathrm{CT}}$ did not alter the conclusion that tendency for a survival advantage in patients with a BMI $\geq 25 \mathrm{~kg} / \mathrm{m}^{2}$ vanished when adjusting for potential confounders $\left(\mathrm{PaCO}_{2}\right.$ and peak work rate [data not shown]). Multiple regression analysis was performed without data imputation; imputing data to take into account missing information in some patients (3, 15 and 21 missing data for $\mathrm{MTCSA}_{\mathrm{CT}}, \mathrm{PaCO}_{2}$ and peak work rate, respectively) did not alter the conclusion of the analysis (data not shown).

\section{DISCUSSION}

Previous studies suggest that obesity is associated with better survival in patients with COPD (16-18). Our results are qualitatively consistent with this observation, although the relatively small sample size precluded calculation of statistical significance for this issue. Nevertheless, univariate analysis showed that increased BMI was positively correlated with survival and, after a mean follow-up period of 72 months, patients with a BMI $\geq 25 \mathrm{~kg} / \mathrm{m}^{2}$ tended to have better survival than those in the lower BMI group. We aimed to distinguish whether the positive association between BMI and survival was due to fat accumulation or to confounding factors. In the present population, the survival advantage of a higher BMI could be explained by the confounding effects of muscle mass, exercise capacity and $\mathrm{PaCO}_{2}$, which with the exception of $\mathrm{PaCO}_{2}$, were all better preserved in patients with $\mathrm{BMI} \geq 25 \mathrm{~kg} / \mathrm{m}^{2}$ compared with their leaner counterparts.

The protective effects of overweight/obesity have been reported in several chronic diseases (11-14), including COPD, particularly in

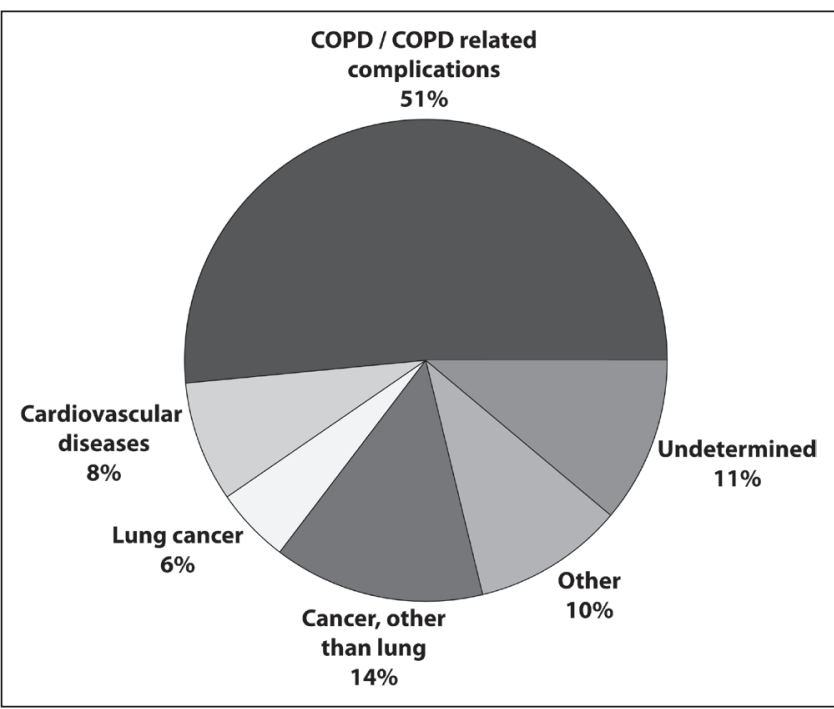

Figure 1) Causes of mortality. COPD Chronic obstructive pulmonary disease

\section{TABLE 2}

Subject's characteristics according to survival status

\begin{tabular}{|c|c|c|c|}
\hline \multirow[b]{2}{*}{ Variable } & \multicolumn{3}{|c|}{ Subjects } \\
\hline & $\begin{array}{c}\text { All } \\
(n=190)\end{array}$ & $\begin{array}{c}\text { Deceased } \\
(n=72)\end{array}$ & $\begin{array}{c}\text { Alive } \\
(n=118)\end{array}$ \\
\hline Age, years & $65 \pm 8$ & $67 \pm 7$ & $64 \pm 9$ \\
\hline Sex, female/male, $n / n$ & $26 / 164$ & $11 / 61$ & $15 / 103$ \\
\hline Height, m & $1.67 \pm 0.08$ & $1.67 \pm 0.08$ & $1.66 \pm 0.08$ \\
\hline Weight, kg & $72 \pm 16$ & $70 \pm 15$ & $73 \pm 16$ \\
\hline $\mathrm{BMI}, \mathrm{kg} / \mathrm{m}^{2}$ & $26 \pm 5$ & $25 \pm 5$ & $26 \pm 6$ \\
\hline $\mathrm{FEV}_{1}, \mathrm{~L}$ & $1.10 \pm 0.46$ & $1.04 \pm 0.47$ & $1.15 \pm 0.45$ \\
\hline $\mathrm{FEV}_{1}, \%$ predicted & $41 \pm 15$ & $39 \pm 16$ & $42 \pm 14$ \\
\hline FVC, L & $2.50 \pm 0.76$ & $2.41 \pm 0.77$ & $2.54 \pm 0.75$ \\
\hline FVC, \% predicted & $72 \pm 18$ & $71 \pm 18$ & $73 \pm 18$ \\
\hline $\mathrm{FEV}_{1} / \mathrm{FVC}, \%$ & $44 \pm 12$ & $43 \pm 11$ & $45 \pm 12$ \\
\hline Peak workrate, W & $65 \pm 33$ & $53 \pm 27$ & $74 \pm 34^{*}$ \\
\hline $\mathrm{PaO}_{2}, \mathrm{mmHg}$ & $81 \pm 12$ & $79 \pm 14$ & $83 \pm 11^{*}$ \\
\hline $\mathrm{PaCO}_{2}, \mathrm{mmHg}$ & $41 \pm 5$ & $42 \pm 6$ & $41 \pm 5$ \\
\hline MTCSA $_{\mathrm{CT}}, \mathrm{cm}^{2}$ & $74 \pm 18$ & $70 \pm 17$ & $77 \pm 17^{*}$ \\
\hline
\end{tabular}

Data presented as mean $\pm S D$ unless otherwise indicated. ${ }^{*} P<0.050$ versus the patients with body mass index $(B M I)<25 \mathrm{~kg} / \mathrm{m}^{2}$. FEV 1 Forced expiratory volume in $1 \mathrm{~s}$; FVC Forced vital capacity; MTCSA $_{C T}$ Mid-thigh muscle crosssectional area obtained using computed tomography scan; $\mathrm{PaCO}_{2}$ Partial pressure of carbon dioxide; $\mathrm{PaO}_{2}$ Partial pressure of oxygen

severe disease $\left(\mathrm{FEV}_{1}<50 \%\right.$ predicted) (16). In patients with milder disease, mortality may rise with $\mathrm{BMI}>30 \mathrm{~kg} / \mathrm{m}^{2}(16)$, possibly because longer survival allows cardiovascular and metabolic complications related to obesity to develop. Understanding the nature of the association between BMI and survival in COPD is relevant to provide adequate nutritional counselling to patients. Our study indicates that caution should be used when interpreting the so-called protective impact of obesity in COPD. For example, the relationship between increased BMI and survival should not be interpreted as indicating that fat accumulation is beneficial.

Using multiple regression analysis, we identified two variables that significantly confounded the relationship between increased BMI and mortality: muscle mass and exercise capacity. The contribution of $\mathrm{PaCO}_{2}$ to this relationship approached statistical significance. Obese patients are characterized by a combined increase in fat and fat-free mass (5). This observation is important because muscle mass better predicts survival than BMI $(2,4,18)$. Although association studies 


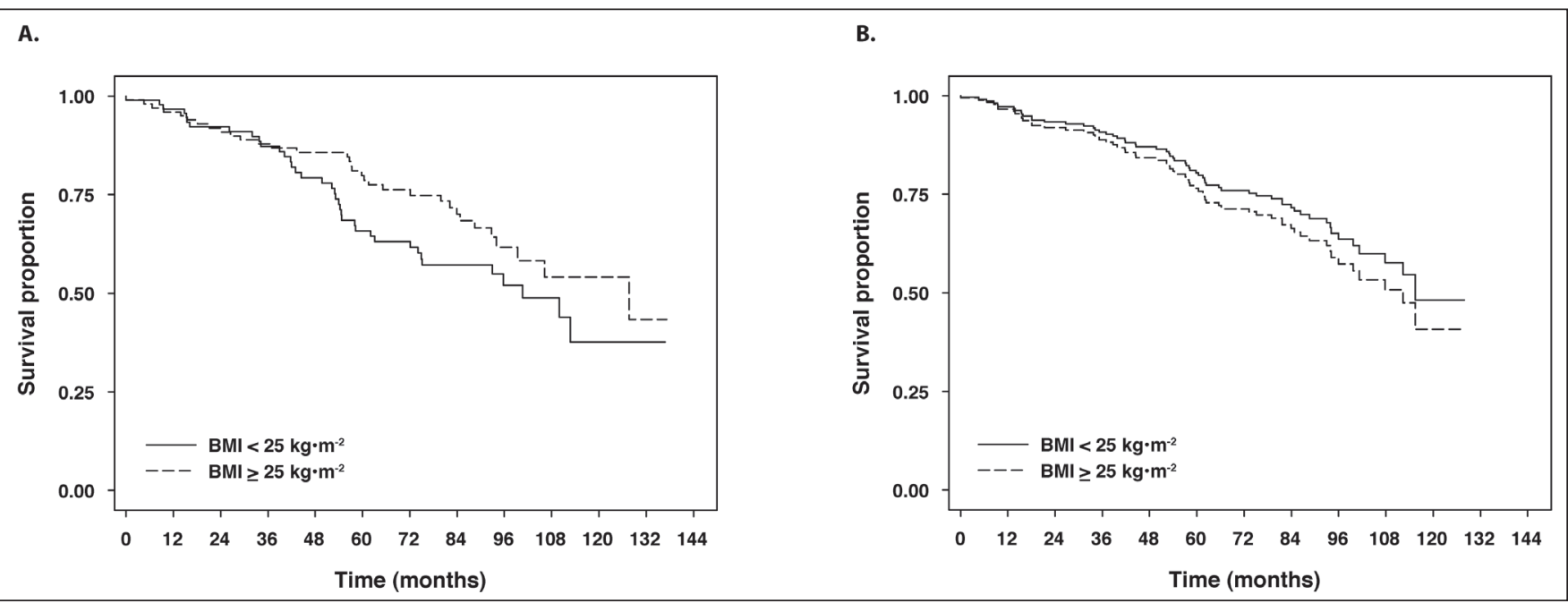

Figure 2) Unadjusted (A) and adjusted (B) survival curves for peak workrate, midthigh muscle cross-sectional area and partial pressure of carbon dioxide according to the two body mass index (BMI) groups. The solid lines represent patients with $B M I<25 \mathrm{~kg} / \mathrm{m}^{2}$ ( $n=91$ ); the dashed lines represent patients with $B M I \geq 25 \mathrm{~kg} / \mathrm{m}^{2}(n=99)$

TABLE 3

Univariate analysis of predictors of mortality

\begin{tabular}{|c|c|c|c|c|}
\hline Variable & $\begin{array}{c}\text { Parameter } \\
\text { estimate }\end{array}$ & HR & $95 \% \mathrm{Cl}$ & $\mathbf{P}$ \\
\hline Age, years & 0.04997 & 1.051 & $1.017-1.086$ & 0.0015 \\
\hline Sex (male, female) & -0.07038 & 0.932 & $0.490-1.774$ & 0.8316 \\
\hline $\mathrm{FEV}_{1}, \%$ predicted & -0.01679 & 0.983 & $0.967-1.000$ & 0.0475 \\
\hline $\mathrm{BMI}, \mathrm{kg} / \mathrm{m}^{2}$ & -0.05647 & 0.945 & $0.900-0.993$ & 0.0188 \\
\hline MTCSACT, $\mathrm{cm}^{2}$ & -0.02236 & 0.978 & $0.965-0.991$ & 0.0007 \\
\hline Peak workrate, W & -0.01498 & 0.985 & $0.976-0.994$ & 0.0007 \\
\hline $\mathrm{PaO}_{2}, \mathrm{mmHg}$ & -0.01784 & 0.982 & $0.961-1.004$ & 0.0969 \\
\hline $\mathrm{PaCO}_{2}, \mathrm{mmHg}$ & 0.05728 & 1.059 & $1.011-1.109$ & 0.0175 \\
\hline
\end{tabular}

BMI Body mass index; FEV ${ }_{1}$ Forced expiratory volume in 1 s; MTCSA $_{C T}$ Midthigh muscle cross-sectional area obtained using computed tomography scan; $\mathrm{PaCO}_{2}$ Partial pressure of carbon dioxide; $\mathrm{PaO}_{2}$ Partial pressure of oxygen

never prove causality, there is a strong biological plausibility underlying the association between muscle mass and survival. Muscle mass is the largest body reservoir of essential amino acids necessary for tissue regeneration (27). Better preserved muscle mass is also associated with better strength, an additional predictor of mortality (28). Exercise capacity is a powerful predictor of survival in several chronic diseases (29) including COPD (20).

Other variables may also influence the relationship between BMI and mortality. An interesting observation was that overweight/obese patients had better preserved respiratory function compared with lean patients as we $(5,6)$ and others (19) have previously reported. One possible mechanism for this observation is that obese patients with COPD may receive medical attention earlier than lean patients, possibly because obesity is also associated with dyspnea (30). Obesity may also counterbalance the effects of COPD on hyperinflation (21), an important prognostic factor in COPD (31). Finally, it is interesting to consider that the longitudinal decline in $\mathrm{FEV}_{1}$ can be slowed as BMI increases in patients with COPD (32).

In interpreting the association between obesity and mortality in COPD, it will be important in future studies to move beyond BMI and to consider fat distribution, on which inflammatory, metabolic and cardiovascular consequences are highly dependant (33). Individuals with a selective accumulation of abdominal/visceral fat are more at risk to develop the metabolic syndrome, diabetes, blood lipid disorders, inflammation or cardiovascular diseases than those who accumulate subcutaneous 'healthy' adipose tissue (33). This observation would appear relevant to COPD because it is an important risk factor for
TABLE 4

Multivariate analysis of mortality predictors

\begin{tabular}{|c|c|c|c|c|}
\hline Variable & $\begin{array}{c}\text { Parameter } \\
\text { estimate }\end{array}$ & HR & $95 \% \mathrm{Cl}$ & $\mathbf{P}$ \\
\hline $\mathrm{BMI} \geq 25, \mathrm{~kg} / \mathrm{m}^{2}$ & 0.20656 & 1.229 & $0.689-2.194$ & 0.4846 \\
\hline Peak workrate, W & -0.01386 & 0.986 & $0.976-0.997$ & 0.0126 \\
\hline $\mathrm{PaCO}_{2}, \mathrm{mmHg}$ & 0.04207 & 1.043 & $0.996-1.092$ & 0.073 \\
\hline $\mathrm{MTCSA}_{\mathrm{CT}}, \mathrm{cm}^{2}$ & -0.02029 & 0.98 & $0.965-0.995$ & 0.0108 \\
\hline
\end{tabular}

BMI Body mass index; MTCSA ${ }_{C T}$ Mid-thigh muscle cross-sectional area obtained by computed tomography scan; $\mathrm{PaCO}_{2}$ Partial pressure of carbon dioxide

cardiovascular diseases (34) and because selective visceral adiposity may occur in this disease $(35,36)$. The presence of obesity in patients with COPD, particularly in its visceral form, may define a clinical phenotype at high risk for cardiovascular diseases. Before recommending patients with COPD to increase BMI with the hope of improving survival, it would be important to have a clearer understanding of which body compartment determines the positive relationship between higher BMI and improved survival. Based on the present study and on the considerations of fat distribution, we suggest increasing muscle mass - not adipose tissue - as a valid therapeutic strategy in COPD.

The present investigation has the merit of assessing, in a cohort of patients with COPD, several important confounders of the relationship between BMI and mortality in COPD. Potential limitations include the fact that lung volumes and diffusion capacity were not measured. In addition, comorbidities were not taken into account in the mortality prediction model - this was believed to be unnecessary because the presence of important comorbidities served as exclusion criteria. The difference in survival between the two groups of patients failed to reach statistical significance. This was likely due the relatively small sample size of our study, leading to a type II error. We calculated, a posteriori, that 910 patients (405 patients in each group) would have been necessary for the study to have $90 \%$ statistical power for the observed absolute difference in survival (8\%) between the two groups of patients to reach statistical significance. Results of the univariate analysis, which was more statistically powerful than group comparisons, demonstrated the positive association between BMI and survival, and was reassuring to the validity of our study. It would have been preferable to categorize patients into underweight, normal weight, overweight and obesity categories. This was not done to avoid compromising the statistical power of our analyses in this relatively small sample of patients with COPD. 


\section{CONCLUSIONS}

In this era, in which we are witnessing an obesity epidemic, the association between obesity and chronic respiratory diseases, such as COPD, is becoming a daily clinical challenge. Because of the robustness of the statistical association between increased BMI and reduced mortality in COPD, clinicians may be tempted to recommend weight gain to their patients. In the present study, we identified important confounders that should be taken into account in future studies investigating the impact of increased BMI on mortality. Overweight/obese patients tended to have better preserved lung function, muscle mass and exercise capacity, all important predictors of mortality in this disease. Therefore, we propose that it is these variables, rather than fat accumulation, that explain why overweight and obese patients are apparently protected against mortality.

\section{REFERENCES}

1. Vestbo J, Hurd SS, Agusti AG, et al. Global strategy for the diagnosis, management, and prevention of chronic obstructive pulmonary disease: GOLD executive summary. Am J Respir Crit Care Med 2013;187:347-65

2. Marquis K, Debigaré R, LeBlanc P, et al. Mid-thigh muscle crosssectional area is a better predictor of mortality than body mass index in patients with COPD. Am J Respir Crit Care Med 2002;166:809-13

3. Soler-Cataluna JJ, Sanchez-Sanchez L, Martinez-Garcia MA, Sanchez PR, Salcedo E, Navarro M. Mid-arm muscle area is a better predictor of mortality than body mass index in COPD. Chest 2005;128:2108-15.

4. Schols AM, Broekhuizen R, Weling-Scheepers CA, Wouters EF. Body composition and mortality in chronic obstructive pulmonary disease. Am J Clin Nutr 2005;82:53-9.

5. Poulain M, Doucet M, Drapeau V, et al. Metabolic and inflammatory profile in obese patients with chronic obstructive pulmonary disease. Chron Respir Dis 2008;5:35-41.

6. Sava F, Laviolette L, Bernard S, Breton M, Bourbeau J, Maltais F. The impact of obesity and overweight on walking and cycling performance and response to pulmonary rehabilitation in COPD. BMC Pulm Med 2010;10:55.

7. Franssen FM, O'Donnell DE, Goossens GH, Blaak EE, Schols AM. Obesity and the lung: 5. Obesity and COPD. Thorax 2008;63:1110-7.

8. van den Bemt L, van Wayenburg CA, Smeele IJ, Schermer TR. Obesity in patients with COPD, an undervalued problem? Thorax 2009;64:640; author reply 640-1.

9. Adams KF, Schatzkin A, Harris TB, et al. Overweight, obesity, and mortality in a large prospective cohort of persons 50 to 71 years old. N Engl J Med 2006;355:763-78.

10. Whitlock G, Lewington S, Sherliker P, et al. Body-mass index and cause-specific mortality in 900000 adults: Collaborative analyses of 57 prospective studies. Lancet 2009;373:1083-96.

11. Lavie CJ, Osman AF, Milani RV, Mehra MR. Body composition and prognosis in chronic systolic heart failure: The obesity paradox. Am J Cardiol 2003;91:891-4.

12. Curtis JP, Selter JG, Wang Y, et al. The obesity paradox: Body mass index and outcomes in patients with heart failure. Arch Intern Med 2005; 165:55-61.

13. Kalantar-Zadeh K, Abbott KC, Salahudeen AK, Kilpatrick RD, Horwich TB. Survival advantages of obesity in dialysis patients. Am J Clin Nutr 2005;81:543-54.

14. Lavie CJ, Mehra MR, Milani RV. Obesity and heart failure prognosis: Paradox or reverse epidemiology? Eur Heart J 2005;26:5-7.

15. Jordan JG Jr, Mann JR. Obesity and mortality in persons with obstructive lung disease using data from the NHANES III. South Med J 2010;103:323-30.

16. Landbo C, Prescott E, Lange P, Vestbo J, Almdal TP. Prognostic value of nutritional status in chronic obstructive pulmonary disease. Am J Respir Crit Care Med 1999;160:1856-61.

17. Schols AM, Slangen J, Volovics L, Wouters EF. Weight loss is a reversible factor in the prognosis of chronic obstructive pulmonary disease. Am J Respir Crit Care Med 1998;157:1791-7.

18. Vestbo J, Prescott E, Almdal T, et al. Body mass, fat-free body mass, and prognosis in patients with chronic obstructive pulmonary disease from a random population sample: Findings from the Copenhagen City Heart Study. Am J Respir Crit Care Med 2006;173:79-83.
ACKNOWLEDGEMENTS: The authors acknowledge the help of Marthe Bélanger, Marie-Josée Breton, Brigitte Jean and Josée Picard for technical support, of Louis Laviolette for editorial assistance and of Gaetan Daigle MSc for statistical analyses.

DISCLOSURES: RG Galesanu was recipient of a research training award of the Respiratory Health Network of the Fonds de la Recherche en Santé du Québec (FRSQ). This work was supported by the Respiratory Health Network of the FRSQ and by an unrestricted grant from GlaxoSmithKline, Canada. François Maltais holds a GSK/CIHR research Chair on COPD at Université Laval.

19. Ramachandran K, McCusker C, Connors M, Zuwallack R, Lahiri B The influence of obesity on pulmonary rehabilitation outcomes in patients with COPD. Chron Respir Dis 2008;5:205-209.

20. Oga T, Nishimura K, Tsukino M, Sato S, Hajiro T. Analysis of the factors related to mortality in chronic obstructive pulmonary disease: Role of exercise capacity and health status. Am J Respir Crit Care Med 2003;167:544-9.

21. Ora J, Laveneziana P, Ofir D, Deesomchok A, Webb KA, O'Donnell DE. Combined effects of obesity and COPD on dyspnea and exercise tolerance. Am J Respir Crit Care Med 2009 15;180:964-71.

22. National Institutes of Health, National Heart Laboratory. Clinical guidelines on the identification, evaluation, and treatment of overweight and obesity in adults - the evidence report. Obes Res 1998;(6 Suppl 2):51S-209S.

23. Bernard S, Leblanc P, Whittom F, et al. Peripheral muscle weakness in patients with chronic obstructive pulmonary disease. Am J Respir Crit Care Med 1998;158:629-34.

24. American Thoracic Society. Standards for the diagnosis and care of patients with chronic obstructive pulmonary disease. Am J Respir Crit Care Med 1995;152:S77-S120.

25. Quanjer PH, Tammeling GJ, Cotes JE, Pedersen OF, Peslin R, Yernault JC. Lung volumes and forced ventilatory flows. Report working party standardization of lung function tests, European community for steel and coal. Official statement of the European Respiratory Society. Eur Respir J 1993;(Suppl 16):5-40.

26. Belsey DA, Kuh K, Welsch RE. Regression diagnostics: Identifying Influential Data and Sources of Collinearity. New York: John Wiley \& Sons, 1980.

27. Kotler DP. Cachexia. Ann Intern Med 2000;133:622-34.

28. Swallow EB, Reyes D, Hopkinson NS, et al. Quadriceps strength predicts mortality in patients with moderate to severe chronic obstructive pulmonary disease. Thorax 2007;62:115-20.

29. Myers J, Prakash M, Froelicher V, Do D, Partington S, Atwood JE. Exercise capacity and mortality among men referred for exercise testing. N Engl J Med 2002;346:793-801.

30. Sin DD, Jones RL, Man SF. Obesity is a risk factor for dyspnea but not for airflow obstruction. Arch Intern Med 2002;162:1477-81.

31. Casanova C, Cote C, de Torres JP, et al. Inspiratory-to-total lung capacity ratio predicts mortality in patients with chronic obstructive pulmonary disease. Am J Respir Crit Care Med 2005;171:591-7.

32. Celli BR, Thomas NE, Anderson JA, et al. Effect of pharmacotherapy on rate of decline of lung function in chronic obstructive pulmonary disease: Results from the torch study. Am J Respir Crit Care Med 2008;178:332-8.

33. Després JP, Lemieux I. Abdominal obesity and metabolic syndrome. Nature 2006;444:881-887.

34. Sin DD, Man SFP. Why are patients with chronic obstructive pulmonary disease at increased risk of cardiovascular diseases? The potential role of systemic inflammation in chronic obstructive pulmonary disease. Circulation 2003;107:1514-9.

35. Furutate R, Ishii T, Wakabayashi R, et al. Excessive visceral fat accumulation in advanced chronic obstructive pulmonary disease. Int J Chron Obstruct Pulmon Dis 2011;6:423-30.

36. van den Borst B, Gosker HR, Koster A, et al. Body Composition S. The influence of abdominal visceral fat on inflammatory pathways and mortality risk in obstructive lung disease. Am J Clin Nutr 2012;96:516-26 


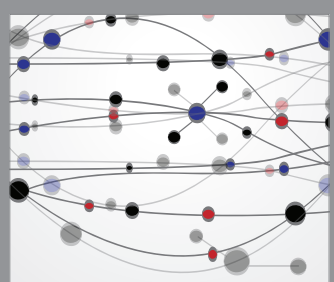

The Scientific World Journal
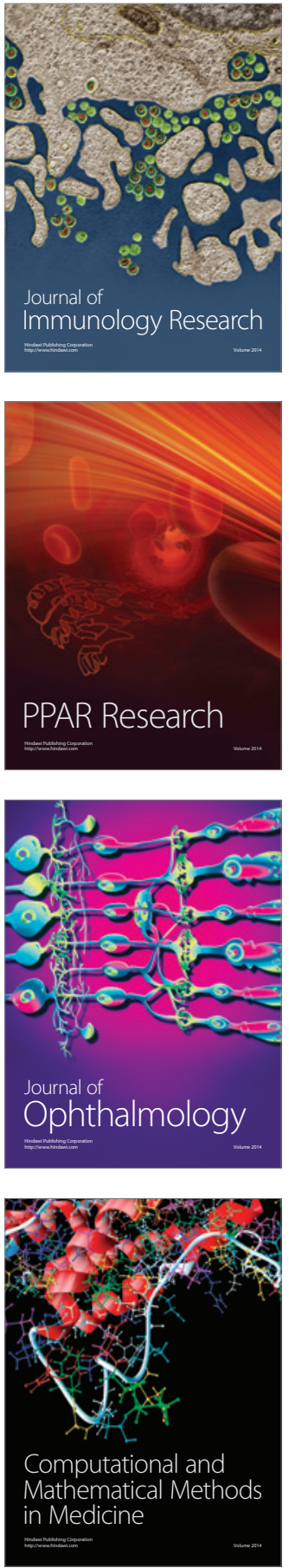

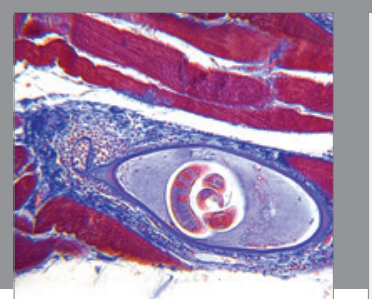

Gastroenterology Research and Practice

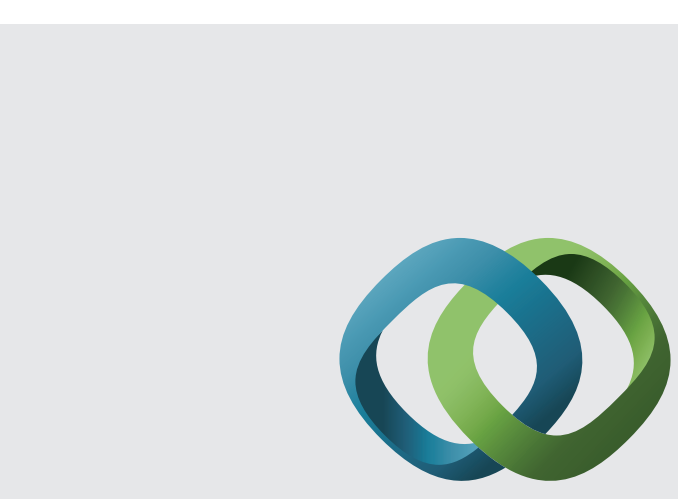

\section{Hindawi}

Submit your manuscripts at

http://www.hindawi.com
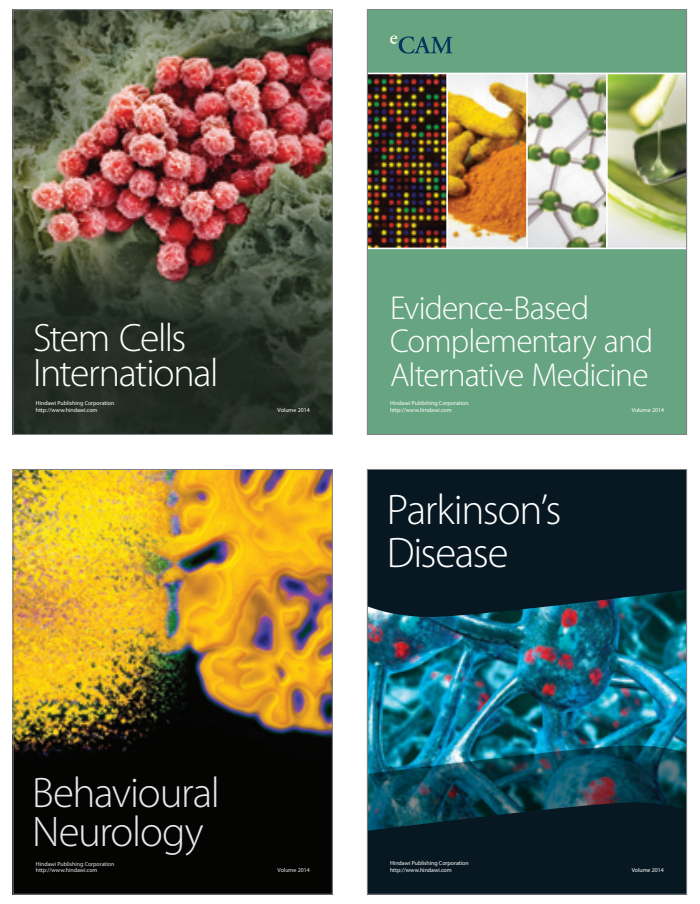
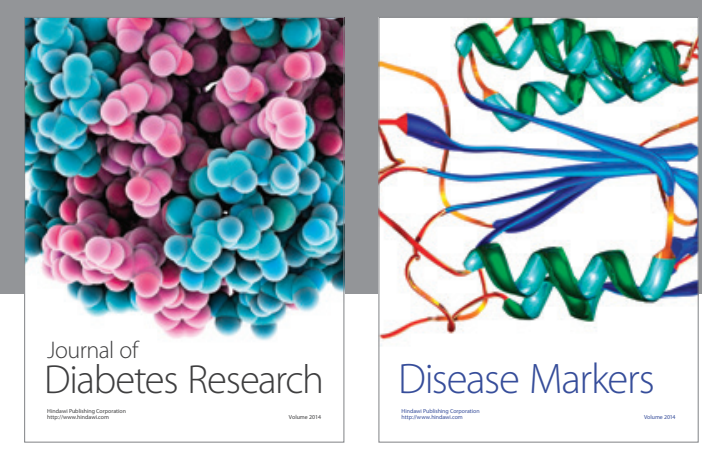

Disease Markers
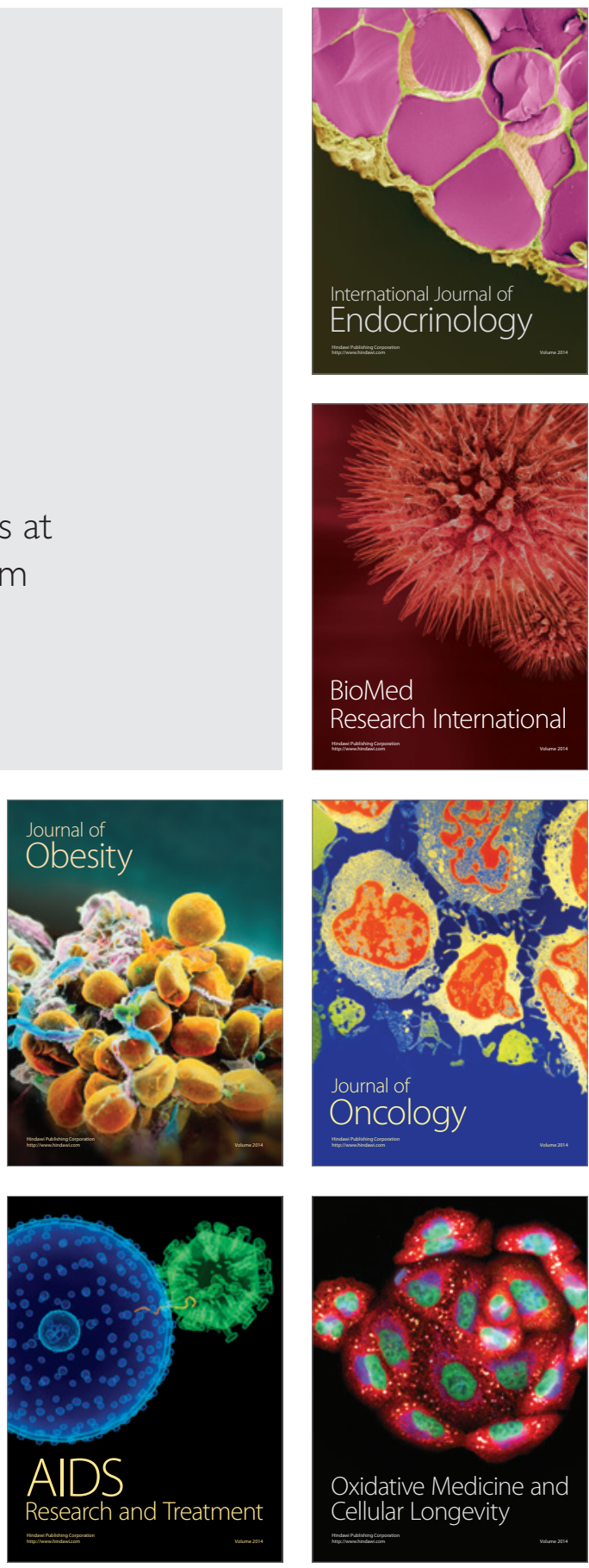